\section{Tropical Diseases Research in Puerto Rico}

THE eighth annual report of the Director of the School of Tropical Medicine of the University of Puerto Rico (under the auspices of Columbia University), recently received, summarises the work of the School during the year ending June 1934. Seminars, lectures and clinics are held weekly in the School, and the Pan-American Medical Association visited the School in March. Much research work has been done, of which an outline is given. This includes a study of tuberculosis and its occurrence in the Island, and a skin test for Brucella infection has been developed. In the Department of Chemistry, work on vitamin A testing of Puerto Rican food plants has been completed. In parasitology, special methods for detecting ova of Schistosoma mansoni have been devised, and some cases of human infection with the liver-fluke, Fasciola hepatica, have been detected. In mycology, infection with new species of ringworm organisms has been found, and the disease known as granuloma inguinale has been investigated. A list of the papers that have been published from the School is appended, together with details of administration and finance.

\section{Twenty-Five Years of Philosophy}

IN recognition of the Royal Silver Jubilee, move. ments in British philosophy during the past twentyfive years have recently been reviewed in the Philosopher (13, No. 3, July 1935). In 1910, Bertrand Russell and A. N. Whitehead crystallised the logistic tradition and created the analytic method. The neorealist creed has been developed by Russell, and the great principle of emergence has taken an important place in modern philosophy, chiefly through the work of C. Lloyd Morgan. These and other systems are, however, opposed by the concept of idealism, the greatest British supporter of which is F. H. Bradley. This reaction against materialism has received much support from British thinkers. Bradley supports absolute idealism, which is closely related to the philosophy of the Hegelians such as Sir James Baillie, Viscount Haldane, etc. Idealism has also found great favour among leading men of science like Sir Arthur Eddington and Sir James Jeans. The antagonism between spiritualism and materialism is exemplified in the controversies concerning animate Nature-vitalism and mechanism. L. T. Hogben supports the latter, but opposed to his views are those of Sir J. Arthur Thomson and J. S. Haldane, who claim the independence of biology from physics. The past twenty-five years has witnessed a welcome approach of philosophy, religion and the positive sciences.

\section{Early Books on the Hyacinth}

UNDER the title "The Voorhelms of Haarlem", Mr. W. Roberts gives an interesting account of some of the Dutch bulb growers, and their literary efforts, during the eighteenth century ( $J$. Roy. Hort. Soc., 60, Part 3, pp. 199-208, May 1935). The Dutch trade in bulbs was established in the seventeenth century, upon a basis of secrecy. The "Dutch Gardener or the
Complete Florist", a book by Henry Van Oosten, published in London in 1703, devoted four pages to the hyacinth and forty to the tulip, but gave away none of the precious information. The publication of "A Treatise on the Hyacinth" by George Voorhelm, in 1752, broke the tradition, and, far from ruining the Dutch trade in bulbs, laid the foundation for development to its present magnificent proportions. The volume was translated into English, French, Italian and German, though no Dutch edition was apparently needed. It was the first scientific treatise on bulb culture, but Mr. Roberts cites many more later volumes on the same subject, and also outlines, in pleasing style, the later development and fortunes of the house of Voorhelm.

\section{Estimation of Small Percentages of Bismuth}

Is view of the need for a generally agreed and reliable method of analysis for the small percentages of bismuth in copper, the Fiscal Policy Joint Committee, Brass, Copper and Nickel Silver Industries in 1933 enunciated, through a specially appointed Technical Sub-Committee, a number of analytical principles to be observed in the estimation. This has now been followed by a detailed method for the determination of quantities of bismuth of the order of $0.0002-0.005$ per cent, based upon published literature on the subject, and the Secretary of the Committee, the address of which is Kings Court, 115 Colmore Row, Birmingham, invites comments from any who are interested.

\section{Mining in South Australia}

THE "Mining Review" of the Department of Mines of South Australia for the half-year ending June 30, 1934, shows that there has been considerable activity in gold mining, due, of course, to the increase in the value of the product. Thus the quantity of gold obtained in 1933 was slightly more than double that obtained in 1932, but its value was considerably more than double that obtained in the previous year, being in fact approximately in the proportion of 7 to 3 . There is also included in the pamphlet a description of a motor-driven rotary drill which has been devised, owing to the difficulty of obtaining fuel and boiler water for the ordinary steam-driven rotary drill.

\section{International Congress of Americanists}

OwING to local difficulties, the twenty-sixth session of the International Congress of Americanists, which should have taken place in 1934, at Seville, was postponed; and at one time it was thought that no meeting would be possible before 1936. Arrangements, however, have been made for the Congress to open at Seville on October 12 next. A programme is being arranged by the Organising Committee, of which S. Gregorio Marañon, president of the Geographical Society, is chairman. The topics selected for discussion include the relations of the individual and the State in the early Spanish expeditions of discovery, conquest and colonisation; types of cities in Spanish America in the colonial period, and the functions of the Hispano-American municipality; social and juridical conditions of the Indians in the 
Spanish colonial period : the critical study of the scientific work as regards geographical knowledge of Spanish America accomplished by the Supreme Council and the "Casa de Contratacion" of Seville; and fundamental problems in the archæology, ethnography and philology of pre-Columbian America. The subscription has been fixed at 25 pesetas. All communications relating to the Congress should be addressed to S. Jose Maria Torroya, General Secretary, calle del Leon, 21, Madrid.

\section{An Active Sunspot}

A RECEnt feature of interest on the sun's disc has been a group of sunspots that appeared suddenly near the central meridian between August 19 and 20. Its growth is shown as follows, the unit of area being one millionth of the sun's hemisphere :

$\left.\begin{array}{crr}\text { Date } & \text { U.T. } & \text { Area } \\ \text { Aug. } 19^{\mathrm{d}} & 8^{\mathrm{n}} & 0 \\ 20 & 8 & 250 \\ 20 & 11 & 350 \\ 21 & 8 & 700 \\ 22 & 8 & 800\end{array}\right\}$ Heliographic position :

On being observed with the Hale spectrohelioscope at the Royal Observatory, Greenwich, the group was obviously very active, especially about the following times: Aug. $20^{\mathrm{d}} 13 \frac{1}{2}^{\mathrm{h}}$; Aug. $21^{\mathrm{d}} 8 \frac{1}{2}^{\mathrm{h}}$ and $9 \frac{1}{2} \mathrm{~h}-10^{\mathrm{h}}$; Aug. $22^{d} 9^{\text {h }}$. During the time that the spots were under observation, there were also continuous minor changes, often too rapid to record in detail, but sometimes producing quite obvious changes in the configuration of the accompanying hydrogen flocculi in less than an hour. On August 21 a stream of relatively dark hydrogen continued for about two hours from $82^{\mathrm{h}}$ to descend with a radial velocity of $40-50$ $\mathrm{km}$./sec. behind the leader spot. About $10^{\mathrm{h}}$ on the same day, after a portion of the flocculi had shown a sudden brightening, a narrow stream of dark hydrogen was shot upwards with a maximum velocity of 140 $\mathrm{km}$./sec., but this faded in about 10 minutes. If this phenomenon had occurred at the edge of the sun, the profile aspect would doubtless have been an exuptive prominence rising to a considerable height.

\section{The Sky in September}

As an offset to the perceptibly shortening days, September provides in the latitude of the British Isles unexcelled night skies to those who search with binoculars or merely use their eyes. By the middle of the month at $21^{\mathrm{h}}$ U.T. $\left(=22^{\mathrm{h}}\right.$ Summer Time), the great triangle formed by Vega, Deneb, and Altair is not far past culmination, whilst crossing the zenith obliquely to the meridian is the Milky Way-a brilliant sight when the moon does not interfere. Arcturus, nearing the north-west horizon, is balanced by Capella in the north-east, and after midnight the Pleiades, Aldebaran, and the head of Orion make the low eastern sky conspicuous. There are also other gems, such as the tiny constellation, Delphinus, the double star cluster in Perseus, and the well-known double star, $\beta$ Cygni. The moon is full on September 12 at $12^{\mathrm{h}}$, and in this lunation becomes the 'harvest moon'. On September 7 it occults $\lambda$ Sagittarii (magnitude $2 \cdot 9$ ), the disappearance of the star taking place in twilight at $19^{\mathrm{h}} 29.5^{\mathrm{m}}$ and the reappearance at $20^{\mathrm{h}} 35^{\mathrm{m}}$. Saturn is the only planet at all well placed for observation ; in the middle of the month it transits about $23^{\mathrm{h}}$. The ring system appears about half-way open. On September $12^{\mathrm{d}} 3^{\mathrm{h}}$, the planet is in conjunction with the moon. Venus is at inferior conjunction with the sun on September 8, when the planet passes $8^{\circ}$ south of the sun's centre; a thin crescent may then be observed telescopically. The variability of Algol ( $\beta$ Persei) may be observed within about $1 \frac{1}{2}$ hours before and after the following times: September $4^{\mathrm{d}} 23 \cdot 6^{\mathrm{h}}, 7^{\mathrm{d}} 20 \cdot 4^{\mathrm{h}}, 25^{\mathrm{d}} 1 \cdot 3^{\mathrm{h}}$, $27^{\mathrm{d}} 22 \cdot 1^{\mathrm{h}}$ and $30^{\mathrm{d}} 18 \cdot 9^{\mathrm{h}}$. The sun enters the sign Libra (Autumnal Equinox) on September $24^{\mathrm{d}} 0^{\mathrm{h}}$.

\section{Announcements}

Dr. Marshalc A. Howe has been appointed director of the New York Botanical Garden as from October 1, in succession to Dr. E. D. Merrill, who has been appointed head of the Botanical Department, Harvard University. Dr. How has been assistant director of the Gardens since 1923. $\mathrm{He}$ has made several field excursions, especially to Newfoundland and the West Indies, and is an authority on the Hepaticæ and marine Algæ of North America.

THE second International Speech Congress will be held in Brussels on September 6-8, under the presidency of Mlle. Hélène Vacaresco, permanent delegate of Roumania at the League of Nations. The subjects for discussion will be instruction in speech, results obtained by the former congress, international exchange of lectures, and French as a universal language. The fee is 20 franes. Further information can be obtained from L'Agence Joseph Dumoulin, 77-79 Boulevard Adolphe Max, Brussels.

A воок by Dr. F. W. Lanchester on "Relativity" will be published by Messrs. Constable and Co., Ltd., on September 5. It presents the theory of relativity and the relationships of space, time and gravitation, in language suited to those who, though not highly specialised in mathematics, wish to grasp the meaning of four-dimensional space-time.

Applications are invited for the following appointments, on or before the dates mentioned :

An assistant vocational guidance officer to the Kent Education Committee-The Director of Education, Springfield, Maidstone (Sept. 7).

An assistant agricultural organiser to the Notts Education Committee-The Director of Education, Shire Hall, Nottingham (Sept. 11).

A mechanical engineer to the Safety in Mines Research Board-The Under-Secretary for Mines, Establishment Branch, Mines Department, Dean Stanley Street, Millbank, London, S.W.1 (Sept. 14).

An assistant librarian in the University of Aberdeen-The Secretary (Sept. 30).

A research fellow, two junior research assistants, and three junior laboratory assistants to the Wool Industries Research Association-The Secretary, Torridon, Headingley, Leeds, 6. 